\title{
Utilitarianism as tort theory: countering the caricature
}

\author{
Craig Purshouse ${ }^{* \dagger}$ \\ School of Law and Social Justice, University of Liverpool, Liverpool, UK \\ ${ }^{\star}$ Author email: craig.purshouse@liverpool.ac.uk
}

(Accepted 5 April 2017)

\begin{abstract}
Utilitarianism, the view that 'actions are right in proportion as they tend to promote happiness, wrong as they tend to produce the reverse of happiness', is no longer taken seriously either as a moral principle or as a theory of tort law. Rights-based theories appear to have won the day. The purpose of this paper is to counter this trend and demonstrate that utilitarianism is not the implausible straw man that its opponents have constructed. Relying upon a version of utilitarianism advanced by the philosopher RM Hare, I will demonstrate that distinguishing between two levels of utilitarian thinking can provide a credible explanatory and normative theory of tort law that is immune to many of the critiques usually levelled at this theory. My final conclusion is that if $a$ rights-based theory of tort law is convincing, it may be one with utilitarian foundations.
\end{abstract}

Keywords: tort law; utilitarianism; rights; private law theory

\section{Introduction}

Utilitarianism, the idea that 'actions are right in proportion as they tend to promote happiness, wrong

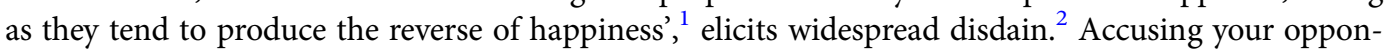
ent of being a utilitarian is treated as a short cut to winning debates. After all, if the caricatures of this theory are to be believed, those who subscribe to it apparently want to sacrifice a minority of people's lives for the sake of the majority's whims, ${ }^{3}$ torture people, ${ }^{4}$ kill new-born babies, ${ }^{5}$ give away all of our money ${ }^{6}$ and encourage eugenics. ${ }^{7}$ What sensible person would take what they say seriously?

\footnotetext{
${ }^{\dagger}$ I would like to thank Jodi Gardner and James Goudkamp for inviting me to present an earlier version of this paper to the Oxford Law Faculty's Obligations Discussion Group in February 2016, where I greatly benefited from the questions and suggestions of those who attended. I am also indebted to Paula Case, John Fanning and the anonymous reviewers of Legal Studies for helpful written comments, and to Søren Holm, Ken Oliphant and Dan Priel for discussing some of these ideas with me.

${ }^{1}$ JS Mill 'Utilitarianism' in J Gray (ed) On Liberty and Other Essays (Oxford: Oxford University Press, 1991) p 137.

${ }^{2}$ For high-profile attacks on utilitarianism see J Rawls A Theory of Justice (Cambridge, MA: Belknap, 1971) pp 26-27; B Williams 'A critique of utilitarianism' in JJC Smart and B Williams Utilitarianism: For and Against (Cambridge: Cambridge University Press, 1973); R Nozick Anarchy, State and Utopia (Oxford: Blackwell, 1974) p 42; and D Parfit Reasons and Persons (Oxford: Oxford University Press, 1984) chs 1 and 2. For a recent critique see A Srinivasan 'Stop the robot apocalypse' London Review of Books (24 September 2015) at 3.

${ }^{3}$ See R Dworkin Taking Rights Seriously (London: Duckworth, 1977) p 205; HLA Hart 'Utilitarianism and natural rights' (1979) 53 Tul L Rev 664, 678; and A Norcross 'Comparing harms: headaches and human lives' (1997) 26 Phil \& Pub Aff 135 at $135-136$.

${ }^{4}$ Cf RM Hare 'The ethics of medical involvement in torture: commentary' (1993) 19 J Med Ethics 138.

${ }^{5}$ See P Singer 'Killing humans and killing animals' (1979) 22 Inquiry 145 at 153-155; A Giubilini and F Minerva 'After-birth abortion: why should the baby live?' (2013) 39 J Med Ethics 261.

${ }^{6} \mathrm{P}$ Singer 'Famine, affluence and morality' (1972) 1 Phil \& Pub Aff 229.

${ }^{7} J$ Savulescu, 'Procreative beneficence: why we should select the best children' (2001) 15 Bioethics 413.

(c) The Society of Legal Scholars 2018
} 
The current vogue for rights-based theories of tort law has exacerbated the negative attitudes directed towards this ethical principle. ${ }^{8}$ Rights-based theories maintain that the law of torts is 'concerned with the secondary obligations generated by the infringement of primary rights'. ${ }^{9}$ When a defendant interferes with a claimant's primary moral rights they have an obligation to provide a remedy. Rights-based theorists position their models in opposition to utilitarianism, of which they are scathing. They believe that maximising good consequences has no place in this branch of the law. ${ }^{10}$ Utilitarianism is supposedly 'barmy' ${ }^{11}$ and a 'long defunct' ${ }^{12}$ theory.

The purpose of this paper is to counter such critiques and provide an explicit philosophical defence of utilitarianism's ability to provide a convincing normative and explanatory account of tort law. Historically, some legal commentators have adopted a utilitarian perspective in their thinking on tort law. ${ }^{13}$ More recently, writers such as Waddams have stated that the 'idea that private law has nothing to do with utility ... [is] not [an] accurate [description] of the past'. ${ }^{14}$ It is also undeniable that many judges rely on utilitarian reasoning when deciding tort cases. ${ }^{15}$ Yet a comprehensive examination of utilitarianism's ability to provide a convincing theory of tort law has been notably absent from the academic literature. ${ }^{16}$ In this respect, this paper will provide a more credible picture of utilitarianism that is often lacking in rights theorists attacks on it.

The argument I pursue takes the following form. First, I give a brief sketch of the fundamental common elements in different versions of utilitarianism. The next part of this paper will outline a type of utilitarianism - namely, the two-level version developed by RM Hare - that does not suffer from the drawbacks of other accounts. I will then demonstrate that, understood properly, utilitarianism is far more persuasive as both a normative (one that proposes how the law ought to be) and explanatory (one that explains why the law is as it is) theory of tort law than it is often portrayed to be. ${ }^{17}$

Before proceeding it is necessary to stress that this paper is necessarily theoretical in nature and that space constraints make it impossible to discuss here how this theory applies to all areas of tort doctrine. ${ }^{18}$ Yet this is not just an esoteric debate that is only of interest to philosophers of private law. Rights theories of tort law are becoming dominant in academia. ${ }^{19}$ If these contributions begin to influence judges then the law will look very different to how it does at present. ${ }^{20}$ For example, many rights

\footnotetext{
${ }^{8}$ For rights theorists who have criticised utilitarianism see E Weinrib 'Towards a moral theory of negligence law' (1983) 2 Law \& Phil 37; E Weinrib The Idea of Private Law (Oxford: Oxford University Press, 1995) p 151; A Beever Rediscovering the Law of Negligence (Oxford: Hart, 2007) p 110; A Beever Forgotten Justice: A History of Political and Legal Theory (Oxford: Oxford University Press, 2013) ch 11. Why are rights theories in vogue? One explanation might be the rise of rights language brought about by the Human Rights Act 1998 and other international conventions.

${ }^{9} \mathrm{R}$ Stevens Torts and Rights (Oxford: Oxford University Press, 2007) p 2.

${ }^{10} \mathrm{R}$ Stevens 'The conflict of rights' in A Robertson and H Wu Tang (eds) The Goals of Private Law (Oxford: Hart, 2009) p 141.

${ }^{11}$ Ibid, p 152.

${ }^{12}$ Stevens, above n 9, p vii (preface).

${ }^{13}$ See OW Holmes The Common Law (London: Belknap, 2009 [1881]) pp 94-96, and JB Ames 'Law and morals' (1908) 22 Harv L Rev 97, 110.

${ }^{14}$ S Waddams Dimensions of Private Law (Cambridge: Cambridge University Press, 2003) p 224.

${ }^{15}$ See Tomlinson $v$ Congleton BC [2004] 1 AC 46 at [81] per Lord Hobhouse.

${ }^{16}$ For example, there is no mention of utilitarianism in Peter Cane's extensive survey of the field: 'The anatomy of private law theory: a 25th anniversary essay' (2005) 25 OJLS 203.

${ }^{17}$ I actually believe that utilitarianism can provide us with a theory of private law, and, for that matter, law more generally. I have focused upon tort law simply because that is where my research interests lie but, given that utilitarianism is a universal principle, the arguments produced here could, by analogy, be applied to other branches of the law.

${ }^{18} \mathrm{I}$ intend to expand upon the application of this theory to tort doctrine in a future monograph.

${ }^{19}$ There have been monographs and edited collections that have taken a rights-based approach to tort law. See Stevens, above n 9, Beever Rediscovering, above n 8, D Nolan and A Robertson (eds) Rights and Private Law (Oxford: Hart, 2011), and N McBride and R Bagshaw Tort Law (Harlow: Pearson, 5th edn, 2015).

${ }^{20}$ For example, in $R$ (Lumba) $v$ Secretary of State for the Home Department [2012] 1 AC 245 the minority in the Supreme Court in favour of awarding 'vindicatory damages' appeared to be influenced by the rights-based theory of tort law.
} 
scholars believe that breaches of public law duties cannot generate private law rights. ${ }^{21}$ They also maintain that 'policy' or social welfare have no role to play in determining tort claims. ${ }^{22}$ Adopting a rights-based framework would mean that decisions such as Kent $v$ Griffiths, ${ }^{23}$ where the Court of Appeal relied upon policy to hold that the ambulance service owes a duty of care to those relying upon its services, may be wrongly decided and should be overturned. ${ }^{24}$ Acceptance of such arguments could see claimants' recourse to the law of torts being restricted. ${ }^{25}$ The fact that this may displease those of us who see the law of tort as serving a protective function would be neither here nor there if the theoretical underpinnings of rights models were sound. But such trends should be resisted when, as I demonstrate below, such theorists have not vanquished utilitarianism as an explanatory or normative framework. Defeating the stale caricatures of utilitarianism mentioned in the first paragraph of this paper is not enough. Without countering the strongest version of utilitarianism, rights scholars will struggle to avoid to accusation that they are attacking straw men.

\section{What is utilitarianism?}

The term 'utilitarianism' was coined by Jeremy Bentham, the founder of the classical school of the theory, in the nineteenth century. ${ }^{26}$ Since then many different versions of the principle have been developed. It would be impossible to chronicle all of them here. ${ }^{27}$ However, it is necessary to sketch the common features contained in utilitarian moral theories. According to Simmonds:

1. Utilitarianism is monistic, in that it proposes one supreme principle (the principle of utility) as governing all moral questions;

2. Utilitarianism is monistic in another respect also: its basic principle (the principle of utility) requires us to maximise a single goal, although the goal may be conceived of differently in different versions of utilitarianism;

3. Utilitarianism is a version of consequentialism. Consequentialist theories claim that the moral rectitude of an action is a function of its expected consequences;

4. Utilitarianism is also individualistic, in the sense that it judges actions, laws and institutions by their impact upon the lives of individuals. Collective goals such as (for example) the creation of a flourishing sense of national identity or fraternity will be accepted by the utilitarian as genuinely valuable only to the extent that they have positive consequences for the lives of individuals. $^{28}$

What might be the single goal that utilitarianism seeks to maximise? For classical utilitarians such as Bentham and John Stuart Mill it was 'happiness', which they interpreted to mean hedonic states. Pleasurable states are the only intrinsic good and pain is the only intrinsic bad. As Bentham stated: 'Nature has placed mankind under the governance of two sovereign masters, pain and pleasure. It is for them alone to point out what we ought to do. ${ }^{29}$ Yet the classical school disagreed about the

\footnotetext{
${ }^{21} \mathrm{R}$ Stevens 'Salvaging the law of torts' in PS Davies and J Pila (eds) The Jurisprudence of Lord Hoffmann (Oxford: Oxford University Press, 2015) p 86; N McBride 'Michael and the future of tort law' (2016) 32 PN 14. Cf the criticisms of this viewpoint in D Priel 'Torts, rights, and right-wing ideology' (2011) 19 TLJ 1 at 13-14.

${ }^{22}$ See Beever Rediscovering, above n 8, p 173, and Stevens, above n 9, ch 14.

${ }^{23}$ [2001] QB 36.

${ }^{24}$ See McBride, above n 21, p 25.

${ }^{25}$ Priel, above n 21.

${ }^{26}$ See JE Crimmins 'Bentham and utilitarianism in the early nineteenth century' in B Eggleston and DE Miller (eds) The Cambridge Companion to Utilitarianism (Cambridge: Cambridge University Press, 2014) p 38.

${ }^{27}$ For an overview see Eggleston and Miller (eds) ibid, and D Brock 'Recent works in utilitarianism' (1973) 10 Am Philos Q 241.

${ }^{28} \mathrm{~N}$ Simmonds Central Issues in Jurisprudence (London: Sweet \& Maxwell, 4th edn, 2013) pp 18-19.

${ }^{29} \mathrm{~J}$ Bentham 'An introduction to the principles of morals and legislation' in A Ryan (ed) Utilitarianism and Other Essays (London: Penguin, 1987 [1789]) p 1. See also JS Mill, above n 1, p 137.
} 
nature of pleasure. Mill opted to separate 'higher' pleasures from 'lower' ones, believing it better to be Socrates unsatisfied than a pig satisfied. ${ }^{30}$ Under this calculation, going to the opera and reading Proust would presumably maximise utility more than spending all day drinking beer and watching reality TV shows. Bentham took a more egalitarian view that did not distinguish between kinds of pleasures: 'the game of push-pin is of equal values with the arts and sciences of music and poetry. ${ }^{\text {, }}$ Instead, the value of pain or pleasure would be determined by its intensity, duration, certainty or uncertainty and its propinquity or remoteness. ${ }^{32}$

And the above divergence relates only to the nature of pleasure. More recent theories perceive the satisfaction of preferences or desires as the goal that should be maximised. ${ }^{33}$ Resolving such debates is not necessary for my purposes. In this paper, I will use the term 'interests' as the goal to be maximised. As a working definition, the one used by Brazier is compelling. An interest as 'a claim or want or desire of a human being or group of human beings which the human being or group of human beings seeks to satisfy'. ${ }^{34}$ People may have interests in experiencing pleasure; they may have an interest in having their desires satisfied: the terminology does not require me to take a specific stance on this issue. The arguments which follow will be just as valid whether one adopts preferences, well-being or happiness as the utilitarian maximand.

It is at this point that I should address the challenge that the utilitarian theory of tort law is indistinguishable from 'economic' or 'wealth maximisation' accounts of tort law. The economic account of tort law sees the goal to be maximised as wealth. As Posner, the doyen of law-and-economics, summarises the theory:

By 'wealth maximisation' I mean a policy of trying to maximise the aggregate value of all goods and services, whether they are traded in formal markets (the usual 'economic' goods and services) or (in the case of 'non-economic' goods or services, such as life, leisure, family and freedom from pain and suffering) not traded in such markets. 'Value' is determined by what the owner of the good or service would demand to part with it or what a non-owner would be willing to pay to obtain it - whichever is greater. 'Wealth' is the total value of all 'economic' and 'non-economic' goods and services and is maximised when all goods and services are, so far as is feasible, allocated to their most valuable uses. ${ }^{35}$

It is undeniable that his approach has some similarities with utilitarianism. Notably, they are both consequentialist in nature. Yet it should be obvious that economic accounts, by perceiving wealth as the intrinsic metric for determining what counts as good consequences, are based upon a narrower maximand than the version of utilitarianism that I advocate. A utilitarian would not dissent from Dworkin's stinging criticism of the wealth maximisation theory: 'Money or its equivalent is useful so far as it enables someone to lead a more valuable, successful, happier or more moral life. Anyone who counts it for more than that is a fetishist of little green paper.' 36

Furthermore, Posner himself goes to great lengths to distinguish his theory from utilitarianism. He believes they are not the same thing, ${ }^{37}$ that wealth maximisation 'provides a firmer basis for a

\footnotetext{
${ }^{30}$ Bentham, ibid, pp $138-139$.

${ }^{31}$ J Bentham The Rationale of Reward (London: J and HL Hunt, 1825) p 206, available at http://bit.ly/1Nmhg9b (last accessed 18 November 2016).

${ }^{32}$ Bentham, above n 29, pp 86-87.

${ }^{33}$ P Singer Practical Ethics (Cambridge: Cambridge University Press, 3rd edn, 2011) pp 14-15.

${ }^{34}$ M Brazier Street on Torts (London: Butterworths, 9th edn, 1993) p 3.

${ }^{35} \mathrm{R}$ Posner 'Wealth maximisation and tort law: a philosophical inquiry' in D Owens (ed) Philosophical Foundations of Tort Law (Oxford: Oxford University Press, 1996) p 99.

${ }^{36} \mathrm{R}$ Dworkin 'Is wealth a value?' (1980) 9 JLS 191, at 201.

${ }^{37}$ Posner 'Utilitarianism, economics and legal theory' (1979) 8 JLS 103, at 103.
} 
normative theory of law than does utilitarianism ${ }^{38}$ and that it cannot 'be deduced from any overarching moral theory, such as utilitarianism'. ${ }^{39}$

It may be countered that the law-and-economics movement is a broad school and more recent versions seek to maximise welfare instead of wealth. ${ }^{40}$ Although I have no objection to maximising welfare, or even to the argument I defend being labelled 'economic' (though calling it that would display an indifference to accuracy), two-level utilitarianism differs from previous consequentialist works on this topic by distinguishing between two levels of utilitarian thinking. The fact that the approach I advocate bears some similarities to economic theories, and that some economic theories have been perceived as defective explanatory accounts of tort law, ${ }^{41}$ does not refute two-level utilitarianism. The argument I outline will still need to be rebutted by those who position their theory in opposition to economic accounts of the law. It is not enough merely to show that the rights theory is more plausible than the work of, say, Posner or other law-and-economists.

Another thing to note here is that a distinction is often made between act and rule utilitarianism. Act utilitarianism is the principle that an act is right only if it produces as much utility as any other act the agent could have performed. ${ }^{42}$ In other words, an agent's act is right if it maximises the overall satisfaction of people's interest; wrong if it does not. ${ }^{43}$

In contrast, rule utilitarianism is the theory that 'an act is right if and only if it would be permitted by a system of rules whose general acceptance would result in at least as much overall well-being as would the general acceptance of any system of rules' ${ }^{44}$ The rightness or wrongness of a particular act is determined by whether it conforms to a set of rules, with those rules having a utilitarian defence or justification. ${ }^{45}$ This notionally leads to better consequences than allowing exceptions to such rules. Again, there is no need for me to discuss the relevant merits of these two theories because, as will become apparent later, the sophisticated two-level theory that I adopt combines the advantages of both act and rule utilitarianism. ${ }^{46}$

\section{The normative theory: two-level utilitarianism}

How, then, might we maximise the satisfaction of people's interests? Hare suggests a convincing answer that involves distinguishing between two levels of moral thinking: ${ }^{47}$

1. The critical level: For use in a 'cool hour,'48 at this level a moral agent is permitted to consider all the details which would enable them to weigh up the course of action that would satisfy the most interests and thus have the best consequences. ${ }^{49}$

2. The intuitive level: This is intended for normal use under conditions of ignorance of the future, stress and temptation, and in moral education and self-education. ${ }^{50}$ At this level we should 'stick to firm and simple principles which are most likely in general to lead to right action'. ${ }^{51}$

\footnotetext{
${ }^{38} \mathrm{Ibid}$.

${ }^{39}$ Posner, above n 35, p 101.

${ }^{40} \mathrm{~L}$ Kaplow and S Shavell 'Fairness versus welfare' (2001) 114 Harv L Rev 961, at 1011-1044.

${ }^{41} \mathrm{~J}$ Goudkamp and J Murphy 'The failure of universal theories of tort law' (2016) 21 LT 47.

${ }^{42} \mathrm{~B}$ Eggleston 'Act utilitarianism' in Eggleston and Miller (eds), above n 26, p 125.

${ }^{43}$ Ibid.

${ }^{44}$ Ibid, p 130.

${ }^{45} \mathrm{D}$ Miller 'Rule utilitarianism' in Eggleston and Miller (eds), above n 26, p 146. See also B Hooker Ideal Code, Real World (Oxford: Oxford University Press, 2000) p 32.

${ }^{46} \mathrm{RM}$ Hare Moral Thinking: Its Method, Level and Point (Oxford: Oxford University Press, 1981) p 43.

${ }^{47}$ Incidentally, distinguishing between two levels of thinking is congruent with recent psychological research regarding how the human brain actually works. See J Greene Moral Tribes (London: Atlantic, 2015) p 133.

${ }^{48} \mathrm{RM}$ Hare 'Critical study: Rawls' Theory of Justice I' (1973) 23 Phil Q 144, 153.

${ }^{49}$ Ibid.

${ }^{50}$ Ibid.

${ }^{51}$ Ibid.
} 
The former of these two levels is used to select the principles to be adhered to in the second level. This distinction between the two levels of thinking indicates that the best way of maximising the satisfaction of interests is to place emphasis upon following rules or acting on shared intuitions in day-to-day moral decisions.

If we were completely rational beings, had unlimited information and 'superhuman powers of clear thinking ${ }^{52}$ then we would be able to find out all the facts and determine what would have the best consequences in each particular case. ${ }^{53}$ Hare calls a perfectly rational being who is exceptional at critical thinking the 'archangel' and a being who is incredibly inept at critical thinking the 'prole'. ${ }^{54}$ Most human beings fall somewhere in between these two extremes. No one is a perfectly rational archangel. Because we are not completely rational and often lack information, attempting to maximise good consequences with each and every action will be counterproductive. We often make mistakes in our thinking, as a wealth of psychological research confirms. ${ }^{55}$ Having everyone behave like an act-utilitarian is therefore unlikely to achieve the best consequences. ${ }^{56}$

Furthermore, by relying upon relatively general principles we are less likely to expose ourselves to special pleading: in practice, 'especially when in haste or under stress, we may easily, being human, "cook" our moral thinking to suit our own interest'. ${ }^{57}$ Human beings are 'notoriously biased"58 in their own favour. We frequently deceive ourselves into thinking something is in the general interest when in reality it is only in our self-interest. Freedom to do what seems right will result in most people doing what is right for themselves.

Another reason why it might be wise to distinguish between the two levels of thinking is that in order to maximise the utility that arises from my act, I have to know, or at the very least be able reasonably to guess, what others are likely to do. Coordination would be impossible in a world populated by act-utilitarians. ${ }^{59}$ For example, people would not expect one another to stick to previously made plans, but regard every decision point as an opportunity for maximising utility. ${ }^{60}$ As Goodin has stated:

The best way to coordinate our actions with those of others, and thereby maximise the utility from each of our actions as individuals as well as from all our actions collectively, is to promulgate rules (themselves chosen with an eye to maximising utility, of course) and to adhere to them. ${ }^{61}$

By following general principles, rules and intuitions we are more likely over the course of our lives to make the decisions that we ought to make than by doing a utilitarian calculation on every occasion. ${ }^{62}$ The intuitive level therefore has an important part to play in moral thinking.

Given this, we should normally rely on general principles when making moral decisions, but in exceptional conditions it is permissible to depart from the intuitive level to the critical one and weigh up which action will produce the most utility. Examples of such circumstances might include those where two of our intuitive convictions conflict in a particular case so both cannot be acted on, or 'when we ask whether the intuitive principles which we have ourselves acquired through our upbringing are the ones which we ought to pass on to our children'. ${ }^{63}$ Such scenarios, though, are likely to be rare. Normally, we should follow rules that have been selected by the principle of utility.

\footnotetext{
${ }^{52} \mathrm{RM}$ Hare 'How to decide moral questions rationally' (1986) 18 Critica 63, at 76.

${ }^{53}$ Ibid.

${ }^{54}$ Hare, above n 46, p 44-45.

${ }^{55}$ See D Kahneman Thinking, Fast and Slow (London: Penguin, 2011) p 156.

${ }^{56}$ See Parfit, above n 2, at 27, and R Crisp 'Utilitarianism and the life of virtue' (1992) 42 Phil Q 139, at 139.

${ }^{57}$ Hare, above n 46, p 38.

${ }^{58}$ Greene, above n 47, p 167.

${ }^{59} \mathrm{R}$ Goodin Utilitarianism as a Public Philosophy (Cambridge: Cambridge University Press, 1995) p 18.

${ }^{60}$ Eggleston, above n 42, p 137.

${ }^{61}$ Goodin, above n 59, p 18.

${ }^{62} \mathrm{Ibid}$, and Hare, above n 46, p 192.

${ }^{63} \mathrm{RM}$ Hare 'Arguing about rights' (1984) 33 Emory LJ 631, 634.
} 
This theory can therefore be described as a sophisticated form of act-utilitarianism that acknowledges the benefits of using rules, principles and intuitions in guiding one's conduct and achieving the best outcomes. Two-level utilitarianism does not see the principle of utility as a decision-making procedure guiding everyday conduct, but instead as the standard of evaluation for morality (ie the correct account of what makes actions and rules right or wrong). ${ }^{64}$ The seeds of this idea appear in Mill's work:

[T] o consider the rules of morality as improvable, is one thing; to pass over the intermediate generalisations entirely, and endeavour to test each individual action directly by the first principle, is another. It is a strange notion that the acknowledgment of a first principle is inconsistent with the admission of secondary ones. ${ }^{65}$

This framework therefore has an important role for rules and moral intuitions but does not use intuition as a basis for the theory. Instead, the criterion of what rights, principles and intuitions we should encourage or enforce is utilitarian in nature.

\section{'Embarrassing' counterexamples}

Before assessing whether two-level utilitarianism can provide a compelling explanation of tort law, it is important to address a common criticism of utilitarianism that supposedly undermines its plausibility as a normative theory. This is the idea that utilitarianism goes against many commonly held intuitions.

Anti-utilitarians have, in Goodin's words, been ingenious at 'concocting painfully cute counterexamples to embarrass utilitarians'. ${ }^{66}$ However, these have 'depicted merely (often barely) possible worlds, more often than probable ones; they have been contrived, more often than commonplace'. ${ }^{67}$ Stevens attempts this method of refutation, believing that according to utilitarianism it would be acceptable to kill you for your valuable organs to further the greater good if it could be demonstrated that this did not undermine the impact of the general prohibition on murder, perhaps if it could be done in secret'. ${ }^{68}$ Under a crude version of the theory it would appear so: deliberately killing one person for their organs could potentially save the lives of people in need of kidneys, a liver, a heart etc. By saving more lives than the one sacrificed it would prima facie satisfy more interests. These conclusions are meant to undermine the plausibility of utilitarianism by establishing that it mandates outcomes that many people believe are repugnant.

However, if one takes the nuanced two-level approach this is not necessarily the case. At the intuitive level, the response to this scenario is fairly simple: killing someone for their organs would be morally unacceptable. ${ }^{69}$ As Hare says, when discussing an example similar to that proposed by Stevens:

A utilitarian does not have to dissent from this verdict at the intuitive level. If he has been well brought up (and in particular if he has been brought up by a sound critical utilitarian thinker) he will have that intuition, and it is a very good thing, from the utilitarian point of view, that he will have it. For just think what would be the consequences of a moral education which contained no prohibition on murder! ${ }^{70}$

\footnotetext{
${ }^{64}$ J Gray 'Indirect utility and fundamental rights' (1984) 1 Soc Phil \& Pol'y 73, 75. Eggleston, above n 42, p 140.

${ }^{65}$ Mill, above n 1, p 156.

${ }^{66}$ Goodin, above n 59, p 6. See Hart's example of a system where slavery could maximise utility, above n 3, p 672. This idea has been critiqued by Hare in 'What is wrong with slavery' (1979) 8 Phil \& Pub Aff 103. See also Nozick's examples, above n 2, pp 41-45, of the 'experience machine' and 'utility monsters' critiqued by Peter Singer in 'The right to be rich or poor' (1975) 22 NYRB, available at http://www.nybooks.com/articles/archives/1975/mar/06/the-right-to-be-rich-or-poor/, for criticisms of this type of argument (last accessed 18 March 2017).

${ }^{67}$ Goodin, above n 59, p 6.

${ }^{68}$ Stevens, above n 9, pp 332-333. Posner uses a similar method, above n 37, p 117, in his argument that a wealth maximisation model is superior to utilitarianism.

${ }^{69}$ Hare, above n 46, p 132. Cf J Harris 'The survival lottery' (1975) 50 Philosophy 81.

${ }^{70}$ Hare, ibid.
} 
So, at the intuitive level it would be wrong to kill someone to use their organs. We certainly would not want a rule that allowed it, as such rules, principles or intuitions are designed to deal with common scenarios. ${ }^{71}$ It is therefore unlikely that the satisfaction of the most interests would be achieved by permitting people to kill each other, or eroding people's aversion to such behaviour. It is for this reason that it would be no defence to a claim in battery to say that one had used the claimant's organs to save the lives of other people. At the intuitive level a utilitarian will arrive at the same conclusion as Stevens on this issue. ${ }^{72}$

But, if we ascend to the critical level, our normal intuitions provide no solution to this problem. After all, they have been developed to help us with the ordinary situations we face in everyday life rather than rigged examples constructed with the express purpose of making murder appear to be the act which maximises utility. At the critical level, it cannot just be assumed that murder has the best consequences in this scenario, as this level requires us to weigh up all of the relevant considerations. Doctors aiming to murder someone for this purpose would have to be very sure that this action would satisfy the most interests as 'if they get it wrong, the consequences will be pretty catastrophic'. ${ }^{73}$ Whose organs are they taking? What if the putative victim is a skilled doctor who could save many more people by being kept alive? As Hare states,

Have [the doctors] absolute confidence in the discretion and support of all the nurses, porters, mortuarists, etc., who will know what has happened? Add to this the extreme unlikelihood of there being no other way of saving these patients, if they can be saved at all, and it will be evident that your opponent is not going to get much help out of this example, once it is insisted that it has to be fleshed out and given verisimilitude. ${ }^{74}$

The fantastical example that Stevens puts forward lacks content and does not, without more, show that murder would satisfy the most interests. Even if Stevens could provide an imagined example where murder would be the course of conduct with the best consequences - and this is doubtful - it is not likely to trouble anyone in the real world and does not disprove utilitarianism as a basis for the rules we should have in place to stop people killing others in our legal system. According to Hare:

... until your opponent produces actual cases, you should not let yourself be troubled overmuch with fictional ones. If the actual cases are produced, you will probably find that the critical discussion of them will leave you and the audience at one, provided that the discussion is serious. ${ }^{75}$

In order to appeal to ordinary intuitions as an argument, opponents of utilitarianism must produce cases which are similar to the sorts of situation that our ordinary intuitions have been designed to deal with. If the cases they use fall outside this class - such as in the fanciful examples often put forward then

... the fact that our common intuitions give a different verdict from utilitarianism has no bearing on the argument; our intuitions could well be wrong about such cases, and be none the worse for that, because they will never have to deal with them in practice. $^{76}$

\footnotetext{
${ }^{71}$ Goodin, above n 59, p 69.

${ }^{72}$ This may depend upon how the question is framed. 'Is killing wrong?' and 'Is it wrong to kill one person to save five others?' may prompt different responses. However, the latter inherently involves a clash between two common intuitive principles (that it is wrong to kill but good to save lives) and so framing it in such a way will require critical thinking.

${ }^{73}$ Hare, above n 46, p 133.

${ }^{74}$ Ibid, p 134

${ }^{75}$ Ibid, p 135.

${ }^{76}$ Hare, above n 66, p. 111.
} 
In this respect, two-level utilitarianism is immune from many of the attacks commonly levelled at this philosophy. $^{77}$

As stated earlier, following particular rules, principles or intuitions, such as avoiding lying, stealing or hitting people (or, to use the tort terminology, defaming individuals, converting their goods or battering them), will maximise utility overall as there are benefits for society in each of us being known as rule-followers or acting on shared intuitions. This is so even if following the rule or intuition might not produce the most utility in that particular instance. ${ }^{78}$ If the above is accepted then utilitarianism can provide us with a normative theory for how the law should develop: in the way that maximises the satisfaction of people's interests.

\section{Utilitarianism as an explanatory tort theory}

In this section, I reveal how this version of utilitarianism can provide a convincing explanation of tort law. Embracing a utilitarian view of tort law does not mean instructing judges hearing tort cases to follow a maxim such as 'secure the outcome that will satisfy the most interests in each case'. Instead, the method of deciding tort cases can be divided into the two levels of thinking discussed above.

The intuitive level of moral thinking is analogous to the doctrine of precedent and the principles that judges follow when deciding tort cases. Having fairly certain rules that protect people's interests allows citizens to interact knowing that minimum standards of conduct will be respected. ${ }^{79}$ As Viscount Simonds said in the The Wagon Mound (No 1): 'civilised order requires the observance of a minimum standard of behaviour. ${ }^{, 80}$ In other words, having rules that protect people's interests through the law of tort enables us to predict how people will behave and arguably leads to good consequences. If judges decided each tort case from scratch based upon what they believed would have the best outcomes, then ultimately the law would not achieve the satisfaction of people's interests. The law would become unpredictable and the result in each case would depend upon the moral opinions of the judge deciding it. As McHugh J recognised in Perre v Apand Pty Ltd., ${ }^{81}$ when the courts formulate legal criteria by reference to indeterminate terms such as what is 'fair' or 'just', the settlement of cases becomes more difficult because practitioners might have inconsistent views of the results of cases if they are litigated. ${ }^{82}$ His Honour said 'Bright line rules may be less than perfect because they are under-inclusive, but my impression is that most people who have been or are engaged in day-to-day practice of the law at the trial or advising stage prefer rules to indeterminate standards. ${ }^{83}$ Accordingly, in order to maximise the satisfaction of people's interests, the judge's role at the 'intuitive level' is to look at the previously decided cases and the relevant legal principles and apply them to the facts at hand.

\footnotetext{
${ }^{77}$ To take another example. Stevens says (above n 9, p 333) 'If it could be shown that the existence and enforcement by law of a right not to be killed, with correlative duties not to do so, led to no fewer deaths and no change for the better in human behaviour, would this be a good argument in favour of its abolition? It would not. It is simply wrong to kill other people; it is not wrong because this leads to fewer deaths.' Leaving aside that his response is pure assertion rather any form of reasoned argument, the example is so outlandish that any intuitions it generates are not reliable in our world. There is a wealth of evidence that laws against killing reduce the level of violence in society (Steven Pinker, The Better Angels of Our Nature (London: Penguin, 2012) pp 71-97), so it is not possible that removing these would result in fewer deaths in our world. As such, any intuitions we might have about such a scenario are wholly unreliable. Our intuitions cannot help us with this rigged example. Moreover, if it was found that our laws increased the number of people being killed then critical thinking might demonstrate that it is best to change them.

${ }^{78}$ Goodin, above n 59, p 18.

${ }^{79}$ See C Witting Street on Torts (Oxford: Oxford University Press, 14th edn, 2015) p 4.

${ }^{80}$ Overseas Tankship (UK) Ltd. Appellants; v Morts Dock \& Engineering Co. Ltd. (the Wagon Mound) [1961] AC 388, 423.

See also A Robertson 'On the function of the law of negligence' (2013) 33 OJLS 31, 32.

${ }^{81}$ [1999] HCA 36.

${ }^{82}$ Ibid, at [81]

${ }^{83}$ Ibid. See also Hunter $v$ Canary Wharf Ltd [1997] AC 655 at 723 per Lord Hope.
} 
Inflexibly following past decisions will provide certainty. But if those decisions are bad ones or no longer socially relevant then they will not maximise overall welfare. To use an extreme example, a rule that someone can own slaves may be easy to follow and will allow us to know, to some extent, how other people are likely to behave. No one who puts their mind to it, though, would advocate that this is a good rule to have: a system of slavery is unlikely to satisfy people's interests.

The benefits derived from having fixed principles can sometimes be eclipsed by the suffering they cause. ${ }^{84}$ Inevitably, there will be situations where it is permissible for judges to depart from the intuitive level of relying upon previous decisions and principles. In such circumstances, they may develop the law. They can do this by ascending to the critical level of thinking. This will involve weighing up what outcome will have the best results and satisfy the most interests. Wider questions of policy and fairness will therefore be appropriate at this stage.

When, then, should judges resort to such critical-level thinking? A case might be novel and so no previous precedent comfortably applies, or changing social facts may mean that a rule is no longer appropriate. In such circumstances, it is legitimate for judges to develop the law and decide the case based upon what outcome would have the best result. One would expect critical thinking to occur more frequently in higher appellate courts than in courts of first instance. Given that the common law is based upon the doctrine of precedent, though, consideration must be given to how the decision might be applied in future analogous cases. This may be difficult to predict and judges will have limited information about the wider impact of their decisions. The critical level should therefore not be the starting point in determining tort cases. ${ }^{85}$ Judges should be aware of the danger that departing from well-established rules in order to achieve a fair result can often result in distortion of the law and a lack of certainty. ${ }^{86}$

The label 'intuitive level' may be something of a misnomer. I am not suggesting that it entails judges deciding tort cases in an unthinking or unanalytical way. The question of what rules are applicable to a particular case can be a difficult one, and the rules that judges rely upon at the intuitive stage might be fairly open-ended and fact-sensitive. Many torts, such as negligence, are quite flexible. Reference to the 'intuitive level' in this context simply means that judges are relying upon precedent, rules and principles rather than broad appeals to 'fairness' or 'policy' more generally.

Distinguishing between these two levels of thinking has the benefit of reflecting the way common law reasoning actually takes place. ${ }^{87}$ Judges rely on previous precedents but do develop the law to achieve a fair result that satisfies the most interests. For example, the Practice Statement ${ }^{88}$ said that the use of precedent was 'an indispensable foundation upon which to decide what is the law and its application to individual cases', ${ }^{89}$ because it provides certainty 'upon which individuals can rely in the conduct of their affairs, as well as a basis for orderly development of legal rules'. ${ }^{90}$ However, it also recognised that 'too rigid adherence to precedent may lead to injustice in a particular case and also unduly restrict the proper development of the law'. ${ }^{91}$

It is not implausible that every judge deciding tort cases has been concerned with the importance of certainty (the intuitive level of utilitarian thinking) and obtaining a fair result that satisfied people's interests (the critical level). However, different judges will have different views regarding the correct balance between certainty and fairness. Some judges believe that following precedent and having clear, certain rules results in the best outcomes. Others believe that issues of fairness should be pre-

\footnotetext{
${ }^{84}$ See K Oliphant 'Against certainty' in S Pitel, J Neyers and E Chamberlain (eds) Tort Law: Challenging Orthodoxy (Oxford: Hart, 2013) p 1.

${ }^{85}$ See C Purshouse 'Arrested development? Police negligence and the so-called Caparo "test" for duty of care' (2016) 23 TLJ $1,12-13$

${ }^{86}$ Wilsher $v$ Essex AHA [1988] AC 1074 at 1092 per Lord Bridge.

${ }^{87}$ See Huddersfield Police Authority $v$ Watson [1947] KB 842 at 848 per Lord Goddard.

${ }^{88}$ [1966] 1 WLR 1234.

${ }^{89} \mathrm{Ibid}$, at 1234 per Lord Gardiner LC.

${ }^{90}$ Ibid.

${ }^{91}$ Ibid.
} 
eminent. ${ }^{92}$ It does not take too strenuous a search of the law reports to find examples of judges having different opinions regarding the balance of fairness and certainty. ${ }^{93}$ They have aimed, overall, to have the best outcomes when deciding tort cases. ${ }^{94}$

Two-level utilitarianism is capable of withstanding the critiques levelled at other tort theories. Murphy's criticism of 'reductionist' tort theorists that ' $\mathrm{t}$ ] he idea that [ judges] were all somehow motivated by a desire to apply, modify or develop the law in a way that was consistent with some kind of overarching norm or principle seems highly implausible ${ }^{95}$ does not apply to the utilitarian theory of tort law. It is possible that judges have been aiming for the best consequences that maximise the satisfaction of people's interests. This is so even if they believe that being concerned with rights or having certain rules that should be consistently applied is the best way to achieve this outcome. It would be startling if judges did not adopt a course that they believed would improve tort law and the lives of people affected by it.

Once the two levels of thinking are distinguished, it becomes apparent that this theory is consistent with the 'historical fact that tort law has been largely cobbled together over several centuries by a great many different (and differently minded) judges in a sometimes ad hoc fashion'. ${ }^{96}$ This is because different judges will give different rights or interests different weight at different times and in different contexts. ${ }^{97}$ No two judges will have exactly the same view of the best method of satisfying people's interests, the extent to which a particular interest should be protected, or how clashes between competing interests should be resolved. But this does not detract from the fact that they were seeking to maximise the satisfaction of people's interests overall. Judges may choose to stick to established rules even when a particular result seems unfair. This is probably because they believe that the judicial function entails sticking to clear rules and that doing so improves welfare overall and in the long term. No judge has developed law with the specific aim of making the world worse.

\section{Illustration: pure economic loss}

An illustration of how this theory applies to tort doctrine might assist us here. For this purpose, I will use the law on recovery for negligently inflicted economic loss because Goudkamp and Murphy claim in a recent paper that it presents significant problems of fit for universal explanatory theories of tort law. ${ }^{98}$ The other recalcitrant areas of tort law that Goudkamp and Murphy believe universal tort theories namely, rights-based, corrective justice and wealth maximisation theories - struggle to explain are the breach element of the action in negligence; liability for negligently inflicted pure economic loss; punitive damages; the defence of illegality; and the rule in Rylands $v$ Fletcher and its descendants. ${ }^{99}$ I believe that, unlike the theories mentioned above, the version of utilitarianism can accommodate these difficult areas of tort doctrine with ease. Space constraints prevent me from undertaking that task here but it should be apparent that the arguments I present on economic loss can be adapted to other aspects of tort law. ${ }^{100}$

In England, a claimant cannot bring a claim in negligence for relational economic loss ${ }^{101}$ or for financial loss suffered as a result of acquiring defective property. ${ }^{102}$ There is a general rule that

\footnotetext{
${ }^{92}$ Lord Denning is a judge who largely ignored precedent (the intuitive level) in favour of what he believed was fair. Pace his - in my view, undeserved - reputation as a great judge, his approach reveals the dangers of judges overly relying upon the critical level of thinking: they are often mistaken about what will have the best results or is 'fair'.

${ }^{93}$ For example, compare the judgments of Lord Buckmaster and Lord Atkin in Donoghue v Stevenson [1932] AC 562.

${ }^{94}$ Waddams, above n 14, p 195.

${ }^{95} \mathrm{~J}$ Murphy 'Rights, reductionism and tort law' (2008) 28 OJLS 393, 393.

${ }^{96}$ Ibid.

${ }^{97}$ See D Priel 'That can’t be rights' (2011) 2 Juris 227, 230.

${ }^{98}$ Goudkamp and Murphy, above n 41, pp 60-63.

${ }^{99}$ Ibid, p 54.

${ }^{100}$ I intend to address how each of the five areas raised by Goudkamp and Murphy do not present a problem for two-level utilitarianism in future work.

${ }^{101}$ See Leigh and Sillavan Ltd. Appellants v Aliakmon Shipping Co. Ltd. [1986] AC 785.

${ }^{102}$ See Murphy v Brentwood DC [1991] 1 AC 398.
} 
negligently inflicted pure economic loss is irrecoverable. ${ }^{103}$ An exception to this is where the claimant can show that their case fits within the extended Hedley Byrne principle. ${ }^{104}$ That is, where there has been reasonable reliance by the claimant upon the defendant's voluntary assumption of the responsibility for a statement or service provided by the defendant and the defendant has special skill or knowledge. In such circumstances, a defendant might owe a duty of care not to cause the claimant financial loss. By contrast, Australia and Canada have no general exclusionary rule against the recovery of pure economic loss. ${ }^{105}$

It is true that the law on negligently caused pure economic loss raises problems for other tort theories. For example, Stevens's rights-based theory contends that there is no right to economic wellbeing but that an assumption of responsibility can create such a legal right. Goudkamp and Murphy believe this cannot explain why pure economic loss can sometimes be recovered in Canada or Australia even when there is no assumption of responsibility. Nor, they suggest, does Stevens's theory satisfactorily explain why English tort law treats an assumption of responsibility as a rights-generating act analogous to gratuitous bailment or estoppel rather than perceiving such gratuitous undertakings as non-binding, as they are in contract law. ${ }^{106}$

In contrast, the law on recovery for pure economic loss in negligence does not present any problems of fit for the two-level utilitarian theory. It is perfectly capable of explaining this aspect of the law. Let us start with the premise that there are (at least) two schools of thought on this issue. One is that pure economic loss should never be recoverable in the tort of negligence. If one wants to protect one's economic interests then the law of contract is the correct route. An alternative view is that the loss of money should be treated in the same way as property damage and, as such, there should be no general exclusionary rule against its recovery. There are, of course, views that fall between these two camps but I will stick with the extremes for the moment.

It should also be remembered that the law of negligence developed from the action on the case, which only protected interests in property or the person. It provided no protection for economic interests. If judges only relied upon the intuitive level of thinking (ie the doctrine of precedent and the concern with certainty) and did not develop the law then pure economic loss would be irrecoverable today.

With this in mind, the law relating to recovery for pure economic loss can be explained (i) by the fact that some judges are more inclined than others to depart from the intuitive level and do what they believe to maximise the satisfaction of interests (to do what they believe is fair); and (ii) by the fact that different judges have different views as to whether it would actually maximise the satisfaction of interests to allow recovery for purely economic loss.

Looking at English law, prior to Hedley Byrne judges generally believed either that it was a good thing to maintain a rule that economic loss should be irrecoverable (that is, that critical thinking meant that disallowing recovery for such losses would maximise the satisfaction of interests), or, if they thought that such loss should be recoverable, that the importance of certainty meant they should stick to previous precedents (the intuitive level), which did not allow recovery for purely economic loss. ${ }^{107}$

The House of Lords in Hedley Byrne believed that it would maximise the satisfaction of interests to allow recovery for pure economic loss in that case. If a different panel in the House of Lords had heard that case then it is unlikely that the exception to the general rule, if it existed at all, would have taken the exact same shape that it has. ${ }^{108}$

Judges deciding cases of negligently inflicted pure economic loss have different views of the correct balance in individual cases between fair results and maintaining certainty (ie the balance between the

\footnotetext{
${ }^{103}$ See Spartan Steel \& Alloys Ltd $v$ Martin \& Co (Contractors) Ltd [1973] QB 27.

${ }^{104}$ Hedley Byrne \& Co Ltd v Heller \& Partners Ltd [1964] AC 465 as extended by Henderson v Merrett Syndicates Ltd. [1995] 2 AC 145.

${ }^{105}$ See Perre v Apand (1999) 198 CLR 180 (Australia) and Kamloops v Nielsen [1984] 2 SCR 2 (Canada).

${ }^{106}$ They outline similar problems of fit for corrective justice theories and for economic theories.

${ }^{107} \mathrm{Cf}$ the dissenting judgment of Denning LJ in Candler v Crane, Christmas \& Co [1951] 2 KB 164.

${ }^{108}$ See P Mitchell 'Hedley Byrne \& Co Ltd $v$ Heller \& Partners Ltd' in C Mitchell and P Mitchell (eds) Landmark Cases in the Law of Tort (Oxford: Hart, 2010) pp 181-183.
} 
intuitive and critical levels). ${ }^{109}$ Additionally, the result of critical thinking is not necessarily uniform. Judges who are willing to move to the critical level of thinking have different views on whether pure economic loss being recoverable in negligence actually would maximise the satisfaction of interests. ${ }^{110}$ Some judges are willing to depart from previous cases in order to restrict recovery for pure economic loss because they believe this will lead to better results. ${ }^{111}$ Judges may all have the same utilitarian aim of satisfying the most interests but different opinions on the best route to achieving this on the subject of pure economic loss. The fact that many areas of tort law appear chaotic can be explained by this divergence of judicial attitudes as to what will lead to the best consequences. As Barker has said of Hedley Byrne, it is the 'focal point for the next grand clash of liberal-economic and welfarist ideologies; for debates about the way in which private law should be organised; about the way our judges reason; and about the respective responsibilities of courts and legislatures in doing justice and dealing with its social effects'. ${ }^{112}$

What about the fact that Australian and Canadian law differs from the current English position? As detailed above, the shape of the law of pure economic loss is largely due to chance and the mindset of which judges decided the key cases. Given the fact that different judges within a single jurisdiction have different opinions as to what the best view of the law is, it should not surprise us that the outlooks of judges in different jurisdictions will also diverge. Once a divergence takes place, tort doctrine in those countries will begin to look different from the law in other jurisdictions.

\section{Divergences in the common law}

This brings us to another way in which utilitarianism is capable of withstanding another of Goudkamp and Murphy's arguments against universal tort theories: that such theories cannot account for divergences in the law in different common law jurisdictions. ${ }^{113}$ They maintain that because divergence is a 'runaway phenomenon'114 then ' $[t]$ he point will eventually be reached, if it has not been reached already, that no single theory will be able to accommodate the diversity of rules that are found across the common law world'. ${ }^{115}$ This critique may be fatal to other accounts of tort law, but utilitarianism is notable for its ability to accommodate the changing facts in our world. The material facts in one country - such as the availability of alternative compensation schemes, the political system, whether it allows jury trials in civil claims, how well public services perform, what welfare benefits are available and so on - will be different from those in other common law jurisdictions. This will have an impact on what satisfies the interests of people in those countries. A rule that will satisfy the most interests in one jurisdiction will not necessarily do so in another where the circumstances of individuals are different. A country with a no-fault compensation scheme for medical accidents or strict environmental regulation may, consequently, have judges who feel less need to develop, respectively, the law of medical negligence and private nuisance in order to satisfy the most interests. The fact that there are differences in the law of torts in different common law jurisdictions does not therefore undermine a utilitarian explanation of the law: it just means judges have been aiming for the best results but have been taking account of the actual interests of people in that jurisdiction in order to arrive at decisions that maximise utility.

\footnotetext{
${ }^{109}$ Compare eg the views of Lord Wilberforce in Anns v Merton LBC [1978] AC 728 at 751 with those of Lord Brandon in Leigh and Sillavan Ltd. Appellants v Aliakmon Shipping Co. Ltd. [1986] AC 785 at 817-818.

${ }^{110}$ Contrast Lord Roskill's statement in Junior Books Ltd $v$ Veitchi Co Ltd [1983] 1 AC 520 at 546 with Lord Bridge's in Caparo Industries plc v Dickman [1990] 2 AC 605 at 618.

${ }^{111}$ See Murphy v Brentwood DC [1991] 1 AC 398.

${ }^{112} \mathrm{~K}$ Barker 'Hedley Byrne $v$ Heller: issues at the beginning of the twenty-first century' in K Barker, R Grantham and W Swain (eds) The Law of Misstatements: 50 Years on from Hedley Byrne v Heller (Oxford: Hart, 2015) pp 24-25.

${ }^{113} \mathrm{~J}$ Goudkamp and J Murphy 'Divergent evolution in the law of torts: jurisdictional isolation, jurisprudential divergence and explanatory theories' in A Robertson and M Tilbury (eds) The Common Law of Obligations: Divergence and Unity (Oxford: Hart, 2015) ch 13.

${ }^{114}$ Ibid, p 299.

${ }^{115}$ Ibid.
} 


\section{Tort statutes}

Goudkamp and Murphy maintain that tort statutes present significant problems of fit for universal tort theories. ${ }^{116}$ This is a convincing criticism of several tort theories. Many statutory provisions require judges to formulate and apply policy. An example that Goudkamp and Murphy present is $\mathrm{s} 1$ of the Compensation Act 2006. This provision states that in determining whether a defendant should have taken particular steps to meet a standard of care in negligence the court may have regard to whether a requirement to take those steps might 'prevent a desirable activity from being undertaken at all, to a particular extent or in a particular way'. ${ }^{117}$ This presents a problem for rights-based and corrective justice theories that reject the idea that policy considerations have any place in tort claims. ${ }^{118}$

A utilitarian is unlikely to object to a command that encourages desirable activities (ie ones that will satisfy people's interests) to be promoted. But even leaving aside this specific legislative provision, these criticisms present no problems for the utilitarian. The legislature, when introducing statutes to reform aspects of tort law, usually believes that it is achieving beneficial consequences. A utilitarian can therefore explain tort statutes: the legislature has also been aiming for the best picture of tort law. Again, whether it has been successful in this endeavour can be assessed by utilitarianism as a prescriptive theory.

For example, in Barker $v$ Corus (UK) plc ${ }^{119}$ a majority of the House of Lords held that where employers were liable on the basis that they had negligently exposed an employee to asbestos and thereby created a material risk of mesothelioma which had eventuated - in other words, where the exception to the normal rules of causation in Fairchild $v$ Glenhaven Funeral Services $L t d .{ }^{120}$ could be established - it would be fair that they should be severally liable only to the extent of the share of the risk created by their breach of duty. Defendant employers would be liable on an aliquot basis rather than jointly and severally. Parliament reversed this ruling with s 3 of the Compensation Act 2006 in respect to mesothelioma claims only: such defendants are liable jointly and severally. This state of affairs is explicable on utilitarian terms: the courts were aiming for the best result and believed this meant holding employers liable on an aliquot basis; the legislature was also aiming for the best result but believed this meant holding employers liable jointly and severally in mesothelioma cases. Who is right? That is a normative question to which utilitarianism can provide an answer: the best result is the one that satisfies the most interests overall. It may be the case that both the courts and the legislature have been horribly mistaken in what they think will satisfy the most interests, but this fails to diminish the fact that their aim is utilitarian in nature. The fact that the outcomes of the current rules of tort law are not ones that a perfect utilitarian would choose does not matter for the explanatory theory of tort law provided that law makers have had utilitarian aims.

\section{Failures to confer benefits}

Stevens provides several objections to utilitarianism. One derives from the fact that there is generally no liability in tort law for failure to confer a benefit. This, he believes, is difficult to explain on utilitarian grounds. Stevens states:

If I fail to pick up a baby drowning in an inch of water or if I take steps to drown him, the end result is the same. If our sole concern was to ensure fewer dead babies, the law would treat the failure to confer a benefit in the same way as conduct worsening another's position. ${ }^{121}$

\footnotetext{
${ }^{116}$ J Goudkamp and J Murphy 'Tort statutes and tort theories' (2015) 131 LQR 133, 136.

${ }^{117}$ See also the similar provisions in the Social Action, Responsibility and Heroism Act 2015 (SARAH Act). This statute requires a court, when assessing breach of duty, to assess whether the defendant was acting for the benefit of society or its members, demonstrated a responsible approach to protecting the safety or interests of others or was acting heroically (ss 2,3 and 4). This statute is not without its own flaws: see J Goudkamp 'Restating the common law? The Social Action, Responsibility and Heroism Act 2015' (2017) 37 LS 577, and Rachael Mulheron 'Legislating dangerously: Bad Samaritans, good society, and the Heroism Act 2015' (2017) 80 MLR 88.

${ }^{118}$ Goudkamp and Murphy, above n 116, pp 146-147. See the references to Stevens and Beever, above n 22.

${ }^{119}$ [2006] 2 AC 572.

${ }^{120}[2003] 1$ AC 32.

${ }^{121}$ Stevens, above n 9, p 94.
} 
There is some force in this criticism. After all, many utilitarian philosophers do not differentiate the consequences that we actively bring about and those that we fail to prevent. ${ }^{122}$ Yet the fact that the law distinguishes between acts and omissions can be explained in utilitarian terms, using the two-levels of thinking: judges may have been overly relying on the intuitive level in this regard. There is, after all, a wealth of precedent indicating that the law recognises a distinction between acts and omissions. ${ }^{123}$ Alternatively, judges might believe that having clear rules that distinguish between acts and omissions will lead to better consequences (whether they are wrong in this belief can, again, be assessed by using utilitarianism as a normative theory). ${ }^{124}$ There are limits to what the law can do, and so even if judges aim for the best consequences, the principles of tort law might not necessarily seamlessly reflect those that a utilitarian philosopher would choose. As Bagshaw has argued:

The fact that legal rules must be applied in practice limits the form that they can take. A legal rule which draws the line between liability and no liability will cause problems unless (1) evidence will be readily available to determine which side of the line a particular case falls, (2) the reliability of that evidence can be established, and (3) the cost of obtaining that evidence and testing its reliability is not too great. $^{125}$

Where these practical problems make it 'unwise to treat a line which a moral philosopher would use to distinguish one part of a group of claimants from another as a legal borderline', ${ }^{126}$ a judge may refuse all such claims, allow all such claims or create arbitrary lines. ${ }^{127}$ The refinements available to a philosopher may not be open to a judge attempting to craft broad rules that can be followed in practice. ${ }^{128}$ One practical problem facing judges is that if the acts-omissions distinction were removed, many more cases would reach the courts than at present. Judges may believe that the implications for the administration of justice would mean it would be better to have an exclusionary rule in such circumstances, even if it results in some deserving claimants going home empty-handed. A stranger standing by and watching a baby drown is immoral, but if we allowed such a claim it might be hard to reject a claim against someone who fails to send money to help children in Syria. A bright-line rule that is unfair to the drowning baby may therefore prevent the difficulties that would occur were such a distinction removed. The omissions rule could be explained in utilitarian terms.

No judge is one of Hare's archangels and so it is perfectly possible that they are mistaken in their beliefs on this and other issues. Just like the rest of us, judges suffer from unconscious bias. The senior judiciary in England and Wales is much more likely than the rest of the population to be male, middle-aged, privately educated and to have attended an elite university. ${ }^{129}$ Most, having worked in the upper echelon of the Bar, will also be wealthier than the average person. These shared characteristics are likely to affect judges' views on what leads to the best consequences. ${ }^{130}$ The typical

\footnotetext{
${ }^{122}$ See Singer, above n 6, p 231, J Harris 'The Marxist conception of violence' (1974) 3 Phil \& Pub Aff 192, and J Harris 'Bad Samaritans cause harm' (1982) 32 Phil Q 60.

${ }^{123}$ See Smith v Littlewoods Organisation Ltd [1987] AC 241 and Michael v Chief Constable of South Wales [2015] UKSC 2, [2015] AC 1732.

${ }^{124}$ See the judgment of Lord Hoffmann in Stovin $v$ Wise [1996] AC 923.

${ }^{125} \mathrm{R}$ Bagshaw 'Children as actionable damage' (2004) 15 KCLJ 117, 125-126.

${ }^{126}$ Ibid, p 126.

${ }^{127}$ Ibid.

${ }^{128}$ Goodin, above n 59, p 21.

${ }^{129}$ See Social Mobility and Child Poverty Commission Elitist Britain? (SMCP 2014) 47, and Judicial Office Statistics Bulletin Judicial Diversity Statistics 2015, available at https:/www.judiciary.gov.uk/wp-content/uploads/2015/07/judicial_diversity_statistics_20151.pdf> (last accessed 18 November 2016).

${ }^{130}$ JAG Griffith The Politics of the Judiciary (London: Fontana Press, 5th edn, 1997) p 293. See also Lord Devlin 'Judges and lawmakers' (1976) 39 MLR 1, 8 where the late Law Lord admitted that judges were more likely to be the type of people who 'do not seriously question the status quo'.
} 
judge's background, class and life experience may unconsciously lead them to believe that what is in the interest of people like them is actually in the public interest. ${ }^{131}$ Marx and Engels recognised this:

Your very ideas are but the outgrowth of the conditions of your bourgeois production and bourgeois property, just as your jurisprudence is but the will of your class made into a law for all, a will, whose essential content is determined by the material conditions of existence of your class. ${ }^{132}$

This may go some way towards explaining tort law's traditional exclusion of liability for omissions and its concern with protecting property rights: the wealthy would be adversely affected if the failure to benefit people was treated as a legal wrong or if the law of tort did not as comprehensively protect private property as it does now. This does not necessarily mean one must become a legal realist, but it may explain why, even if judges may have been aiming for the best consequences in maintaining a distinction between acts and omissions, it does not necessarily mean they have been successful in this endeavour.

\section{Judges do not weigh the costs and benefits of imposing liability in every tort case}

Stevens advances another rebuttal to utilitarianism when he argues that the costs and benefits of imposing liability in tort are 'not aggregated in a utilitarian manner'. ${ }^{133}$ Some interests, for example lives and money, are incommensurable and 'cannot be weighed in the scales in the manner which a utilitarian approach requires'. ${ }^{134}$ This assertion is peculiar. At one point in Torts and Rights, Stevens states that adopting his rights model 'does not mean that we should pay any price for a legal system which recognised and enforced such a right. If the legal system ate up 90 per cent of the gross domestic product we might conclude that the enforcement of such moral rights by law was not worth the candle. ${ }^{135}$ If moral rights such as the right to life cannot be compared with money, why would the fact that protecting the right to life was costing 90\% of GDP mean we should not enforce the right? If money and rights are incommensurable then it would not be possible to say whether spending so much money on protecting the right to life would be a good or a bad thing.

More importantly, and leaving aside the fact that rights theorists face the difficulty of explaining cases where judges have explicitly engaged in such balancing exercises, ${ }^{136}$ a utilitarian need not dissent from the premise that judges do not weigh up the costs and benefits of imposing liability on a defendant in tort cases in an aggregate manner. This is because judges rely upon prima facie principles and established precedents at the intuitive level of thinking. Weighing up the costs and benefits of imposing liability should only take place in exceptional circumstances at the critical level. Distinguishing between the two levels of thinking means that one can deflect Stevens's criticism. Indeed, this type of argument is one that Mill made short work of:

To inform a traveller respecting the place of his ultimate destination, is not to forbid the use of landmarks and direction-posts on the way. The proposition that happiness is the end and aim of morality, does not mean that no road ought to be laid down to that goal. ${ }^{137}$

Similarly, the fact that 'the law does not apply a uniform standard in assessing conduct, whether a negligence standard or any other' ${ }^{138}$ does not, pace Stevens, refute utilitarianism as an explanatory theory of tort law. ${ }^{139}$ The fact that some torts require fault and some do not is a historical

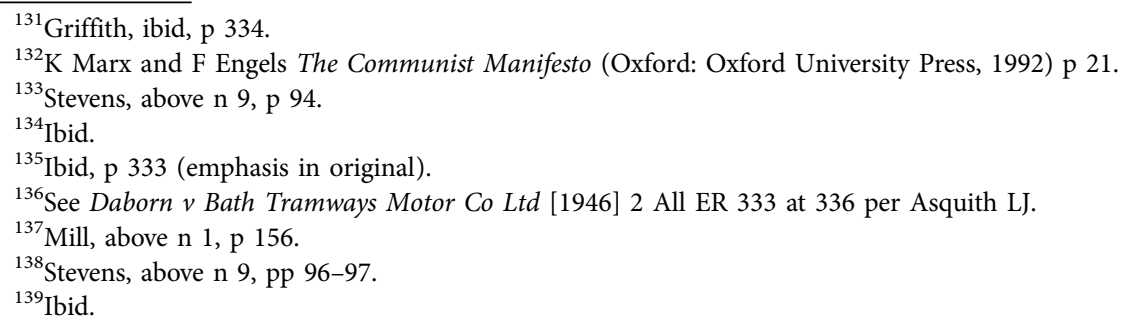


accident. ${ }^{140}$ Again, the current shape of tort law can be explained by the fact that judges rely upon prima facie principles and the doctrine of precedent. Even the most radical judge is not going to reshape the entire law of tort from scratch in the manner he or she thinks will satisfy the most interests. ${ }^{141}$ This explains why there is no consistent single principle of liability: common law judges favour incremental reform. Whether this is the best system to have, according to utilitarianism, is a normative question. Perhaps a single principle of liability would lead to better outcomes. However, the case is not so overwhelming that a judge should be condemned for ignoring the previous authorities and established causes of action in order to implement such a principle.

\section{Conclusion: a utilitarian theory of tort law's rights?}

Let me conclude back where I started, with the rights-based critiques of utilitarianism. The sophisticated two-level utilitarianism propounded by Hare can deflect many of the criticisms levelled at crude versions of this philosophy. It provides us with a plausible normative and explanatory theory of tort law: tort law should aim to maximise the satisfaction of interests and law makers have been aiming for the best consequences while taking account of the importance of certainty in the law. What does this mean for a rights-based view of tort law? Given that Bentham described appeals to natural rights as 'nonsense upon stilts', ${ }^{142}$ it might be tempting for utilitarians to regard such theories as unsalvageable. Such dismissals would be premature, though. Using two-level utilitarianism, a credible rights-based view of tort law can be put forward (although the resulting law would probably differ from the one that many rights theorists desire).

Utilitarianism is not inconsistent with the protection of moral rights. ${ }^{143}$ Rights have a place in a utilitarian moral framework and, by extension, in a utilitarian theory of tort law, because they can function as prima facie principles. They belong to the intuitive level of moral thinking. ${ }^{144}$ Questions surrounding what rights we should have or how clashes between competing rights should be resolved are matters which invite critical thinking: we should recognise the rights that are likely to maximise the satisfaction of people's interests and, where clashes between rights occur, favour the rights that will satisfy people's interests overall and in the long run. Thus, rules such as, say, not allowing people to be falsely imprisoned are ones that will appeal to rights theorists but their basis will be utilitarian. Judges need prima facie principles when deciding tort cases and the critical level of thinking will have resulted, over time, in the selection of those principles. The method of selecting the principles will be utilitarian 'but the principles themselves may not themselves look utilitarian at all'. ${ }^{145}$ This presents a coherent methodology for determining the rights that people have, as we can use a single yardstick the principle of utility - to resolve conflicts between rights. ${ }^{146}$ If we distinguish the two levels of thinking, utilitarianism might allow us to have the benefits of a rights-based system (clear rules that protect people's interests and provide certainty) but provides a more compelling basis for it. Conflicts between

\footnotetext{
${ }^{140}$ See eg J Murphy 'The merits of Rylands $v$ Fletcher' (2004) 24 OJLS 643, 649.

${ }^{141}$ See Hunter $v$ Canary Wharf Ltd. [1997] AC 655 at 696 per Lord Lloyd: '[I]t is one thing to modernise the law by ridding it of unnecessary technicalities; it is another thing to bring about a fundamental change in the nature and scope of a cause of action.'

${ }^{142}$ J Bentham 'Anarchical fallacies' in B Parekh (ed) Bentham's Political Thought (London: Routledge, 2016) p 269.

${ }^{143}$ See D Priel 'Land use priorities and the law of nuisance' (2015) 39 MULR 346, 356, and I Persson, 'The groundlessness of natural rights' (1994) 6 Utilitas 9. Cf Dworkin, above n 3, ch 12, and HLA Hart Essays on Bentham (Oxford: Oxford University Press, 1982) p 94, but see J Raz 'Hart on moral and legal duties' (1984) OJLS 123 for a critique of Hart's arguments.

${ }^{144}$ Hare, above n 46, p 153.

${ }^{145}$ Ibid, p 162.

${ }^{146}$ The issue of conflicting rights is one that Stevens and other rights theorists struggle with. Stevens has written 'Where one right conflicts with another the law must "strike a balance" between the two' and that 'there is not always necessarily one demonstrably right answer as to how these conflicts are to be settled. Irreducibly, judgement is required' (above n 10, p 168). The defectiveness of this approach, though, is that it rests upon the intuitions of the decision maker. While it is not a problem that intuitive thinking occurs in moral and political argument, Stevens never provides us with a method for determining issues at the critical level. He relies upon intuition as the justification for the rights tort recognises and so he has no convincing argument to offer those who do not share his intuitions.
} 
rights can be adequately dealt with, and the satisfaction of more interests can be achieved by ensuring that the rights that we do recognise are the best ones to have. Ultimately, it may be better to have a system that does not allow rights preventing people from being battered, run over or falsely imprisoned to be lightly set aside for marginal utility gains. Interpreting the law of tort as being concerned with the protection of rights is therefore not inconsistent with utilitarianism provided that some critical thinking occurs in the appropriate circumstances.

There is a useful debate to be had as to whether perceiving tort law as being concerned with people's moral rights will ultimately lead to the best outcomes. Many scholars believe that viewing tort law as a system to protect our rights leads to a more coherent picture of the law. It may be the case that this will satisfy the most interests overall and in the long run. ${ }^{147}$ It might not. A more flexible system might be more conducive to this aim. It could even be the case that abolishing the tort system altogether would maximise utility. ${ }^{148}$ The question of what rights should be protected, or whether tort law should protect rights at all, is a normative question. I do not intend to answer it here.

Embracing a two-level utilitarian framework does not necessarily provide easy answers to controversial tort debates. As an explanatory and normative theory of tort law, it is at a high level of abstraction. Should we allow judges to take account of policy, or should they stick to principle? Is it better to focus on the claimant's rights or the defendant's faulty conduct? When will utility be maximised by departing from bright-line rules that are relatively certain and easy to discover? These are definitely not new questions, and disagreement about them is unlikely to go away. No one, after all, is perfectly rational, and we all have our own biases which affect what we think will lead to the satisfaction of the most interests. But if we adopt a common yardstick in our descriptive and prescriptive analysis and distinguish between the two levels of utilitarian thinking, at least everyone will be arguing from the same premises rather than at cross-purposes. This might lead to a more fruitful discussion of such issues in future tort scholarship.

\footnotetext{
${ }^{147}$ See R Bagshaw 'Tort law, concepts and what really matters' in Robertson and Tang, above n 10, p 249.

${ }^{148}$ PS Atiyah The Damages Lottery (Oxford: Hart, 1997) p 189.
}

Cite this article: Purshouse C (2018). Utilitarianism as tort theory: countering the caricature. Legal Studies 38, 24-41. https:// doi.org/10.1017/lst.2017.6 